\title{
The Happy Farmer: Self-Employment and Subjective Well-Being in Rural Vietnam
}

\author{
Thomas Markussen $^{1} \cdot$ Maria Fibæk $^{2} \cdot$ Finn $\operatorname{Tarp}^{1,3}$ (D) \\ Nguyen Do Anh Tuan ${ }^{4}$
}

Published online: 15 May 2017

(C) UNU-WIDER 2017. This article is an open access publication

\begin{abstract}
Using a unique survey data set this paper documents a positive effect of selfemployment in farming on subjective well-being. This direct effect is only partly offset by negative, indirect effects working through income and other variables. These findings are interpreted as effects of self-employment in farming on perceived autonomy, competence and relatedness. The results suggest that economic transformation is associated with a psychological cost, which may contribute to explaining earnings gaps between sectors and types of employment. We also investigate other determinants of happiness, and for example find strong positive effects of own income and strong negative effects of neighbors' income, suggesting the importance of relative rather than absolute levels of income.
\end{abstract}

Keywords Happiness · Self-employment · Wage work · Agriculture · Vietnam

\section{Introduction}

Many developing countries are undergoing a process of 'structural transformation' in which large numbers of workers move from agriculture to other sectors and from self-employment into wage work. This study investigates the consequences of this process for subjective wellbeing. Using data from Vietnam, we focus on the effects on happiness from being self-

The original version of this article was revised: The copyright line has been changed from The Author(s) 2017 to UNU-WIDER 2017.

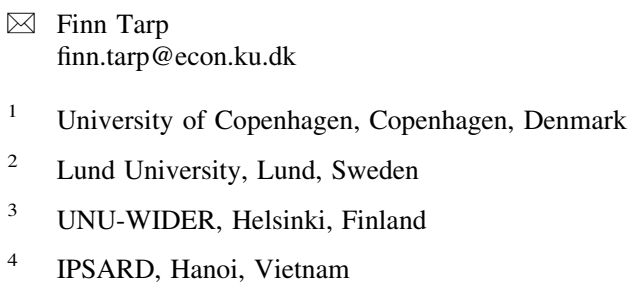

4 IPSARD, Hanoi, Vietnam 
employed in farming, as opposed to working for a wage or being self-employed in nonfarming. The analysis contributes to the growing, but still relatively small literature on happiness in developing countries. ${ }^{1}$ Apart from self-employment, we investigate other, potential determinants of subjective well-being, including income, age, gender, marital status, schooling, migration, social networks, and economic shocks. ${ }^{2}$

Vietnam is experiencing fast structural transformation and economic development. The share of the labor force in agriculture dropped from $70 \%$ in 1996 to $47 \%$ in 2012 . The share of selfemployed dropped from 83 to $65 \%$ over the same period and these trends are set to continue over the coming decades. ${ }^{3}$ While such occupational shifts play an important role in generating increased productivity and income (e.g. McMillan and Rodrik 2011) they may also have important effects on subjective well-being. Benz and Frey (2008a, b) show that self-employment is associated with significantly higher job satisfaction than wage labor in a number of countries and ascribe this effect to higher levels of 'procedural utility' for the self-employed. The move from agriculture to non-agriculture may also affect subjective well-being. Most people in rural areas were raised on a farm and may feel most competent in this environment. Also, working on a family farm often allows one to maintain close relations with parents and other family members.

Below, we show that the hypothesis of a positive effect of self-employment in farming on subjective well-being can be derived from self-determination theory, an influential, psychological theory of human motivation (Deci and Ryan 1985, 2000). We then use data from a rural household survey in 12 provinces of Vietnam to test this hypothesis. Our measure of happiness is a one-item survey question asking respondents to state how pleased they are with their lives. It is a measure of 'life evaluation', as opposed to 'emotional well-being' (Kahnemann and Deaton 2010).

Results show, first, that the level of subjective well-being in rural Vietnam is low. This may be surprising given that rapid economic progress is taking place. Some $48 \%$ of respondents report being 'not very' or 'not at all' pleased with their lives. Second, there is a substantial, positive effect of self-employment on happiness. This effect is largely driven by self-employment in farming, rather than self-employment in other sectors. The difference between self-employment in farming and wage work appears only partly to be transitory and is not driven by particular types of wage work; rather it applies across many different types of jobs. The effect of self-employment in farming is strongest when income and other intermediate outcomes are controlled for, but is also significant when they are not. These findings highlight the psychological cost associated with the transition from working on family farms to wage work and self-employment in non-farming.

These results of digging into what Berry (2008) refers to as a third and fourth level of labor market analysis potentially contribute to explaining earnings gaps between formal and informal sectors and between agriculture and other sectors. The presence of such differences is a key observation underpinning classic models of economic development, such as Lewis (1954), Ranis and Fei (1961), and Todaro (1969). Earnings differentials have been explained as the result of transport frictions, minimum wages, union bargaining, unemployment, and other factors (e.g. Stiglitz 1974; Teal 1996). Differences in 'procedural utility' associated with different types of employment are an alternative or complementary explanation, as wage workers in industry and services may demand monetary compensation for the psychological cost of working in these types of jobs.

\footnotetext{
1 Examples of other studies on happiness in developing countries are Deaton (2008), Graham and Petinatto (2001), Graham (2005a, b), Brockmann et al. (2008), and Knight and Gunatilaka (2010a, b).

2 We use the terms subjective well-being and happiness interchangeably.

3 See World Development Indicators at http://data.worldbank.org/.
} 
The study is organized as follows: Sect. 2 discusses the potential effects of self-employment in farming on happiness, in the light of self-determination theory. Section 3 describes the data and Sect. 4 presents the variables used and the analytical model. Section 5 provides descriptive statistics and Sect. 6 presents regression results for the effects of self-employment on happiness. Section 7 discusses the effects of various control variables including income, and Sect. 8 concludes.

\section{Self-Employment, Agriculture, and Happiness}

Our hypotheses about the effects of self-employment are based on the economic concept of 'procedural utility' (Frey et al. 2004), which in turn relies on self-determination theory (SDT) (Deci and Ryan 1985, 2000). People are said to obtain procedural utility when their well-being is affected not only by the final outcomes they achieve but also by the process of reaching those outcomes. For example, different types of employment may yield different (procedural) utility, even if they generate the same income. SDT helps us understand which attributes of employment are important for determining procedural utility. SDT posits the existence of three, fundamental, psychological needs, namely autonomy, competence and relatedness. Autonomy is essentially the freedom to act in accordance with one's values. Competence is the experience of mastering one's environment. Relatedness refers to the 'desire to feel connected to others' (Deci and Ryan 2000, p. 231). Proponents of SDT stress that these are not culture-specific; they are universal, human needs. ${ }^{4}$

In their influential papers about the effects of self-employment on job satisfaction and subjective well-being, Benz and Frey (2008a, b) stress the importance of autonomy. Positive effects of self-employment are interpreted as resulting from procedural utility generated by higher autonomy on the part of the self-employed, relative to wage workers. Other empirical results can be viewed as supporting this interpretation. Most studies of developed countries find a positive effect of self-employment on happiness and/or job satisfaction. Blanchflower and Oswald (1998), Blanchflower et al. (2001), Blanchflower (2004), Andersson (2008), Fuchs-Schündeln (2009), Alesina et al. (2004) all document such effects. Results on occupation and subjective well-being in developing and in transition countries are more mixed. Graham (2005a) presents results on the effect of selfemployment in both Russia and Latin America (using a pooled sample from the Latinobarometro survey in the latter case). She finds that in Russia, the self-employed are on average happier than wage workers, whereas in Latin America the self-employed are less happy. Graham and Petinatto (2001) use data from 17 Latin American countries and show that being self-employed has no significant effect on happiness. Bianchi (2012) shows that the positive effect of self-employment on job satisfaction is conditional on financial sector development. In the countries with the least sophisticated financial markets, there is no significant effect of self-employment. Both Graham (2005b) and Bianchi (2012) interpret their negative or insignificant findings as the result of self-employment being less of a choice in some developing countries than in developed countries. If people are selfemployed only because no wage work is offered, their experience of autonomy is likely to be reduced and the effect of self-employment on happiness may vanish. ${ }^{5}$

\footnotetext{
4 Particularly, autonomy is not synonymous with independence or individualism, which may be regarded as specifically Western values, see e.g., Deci and Ryan (2000, p. 247).

5 Some papers do document positive effects of self-employment in developing countruies. Benz and Frey (2008b) examine the effects of self-employment on job satisfaction in 23 countries, of which two are
} 
We do not dispute the claim that increased autonomy is potentially an important effect of self-employment, particularly when self-employment is freely chosen. However, we point out that mode of employment may also impact on the fulfilment of other psychological needs, such as competence and relatedness. Particularly, we hypothesize that in the rural areas of a developing country, residents are likely to feel more competent and more closely related to other people, particularly family members, if they work on a family farm than in most other types of employment. Farmers are likely to feel more competent than other people because most people in rural areas (including the non-farmers) were brought up to be farmers. Even if they have received formal schooling, much of their socialization prepared them to be farmers. Working in agriculture could increase relatedness for two reasons. First, farmers typically work in the same, physical location as where they live. This strengthens ties to spouse, children and possibly other family members. Second, since farming was even more common in previous generations than in the present, most people's parents are/were farmers. Being a farmer oneself is likely to strengthen bonds with the elder generation of one's family, regardless of whether they live in the same house as oneself. This might be particularly important in the Vietnamese context, where family relations are considered by most people to be highly important. The 2001 World Values Survey in Vietnam asked respondents about the importance of different 'life domains'. Some $82 \%$ of respondents say that the family is 'very important', while $57 \%$ regard 'work' as very important. Only $22 \%$ rank 'friends' as very important (Dalton et al. 2002).

Together, these considerations lead to the hypotheses that, ceteris paribus:

(1) There is a positive effect of self-employment on subjective well-being.

(2) This effect is strongest for those self-employed in farming.

To summarize the discussion above, the first effect is theorized as mainly driven by autonomy, while the latter is mediated by competence and/or relatedness. To our knowledge, no previous study of subjective well-being has investigated differential effects of self-employment in farming and non-farming on subjective well-being. Also, while a large literature investigates the three dimensions of self-determination (Deci and Ryan 2000 and the references therein), we do not know of other studies that specifically relate the concepts of competence and relatedness to the discussion about effects of self-employment on happiness.

\section{Data}

Our empirical analysis is based on the 2012 wave of the Vietnam Access to Resources Household Survey (VARHS), implemented in the rural areas of 12 provinces in Vietnam between June and August 2012. VARHS re-interviewed rural households sampled for the income and expenditure modules of the 2002 and 2004 Vietnam Household Living

Footnote 5 continued

developing (the Philippines and Bangladesh). They find positive effects of self-employment in both countries. Blanchflower (2004) uses data from 78 countries in the World Values Survey (WVS) and presents pooled regression results on the effects of self-employment on life satisfaction. The estimated effect is positive but insignificant. Falco et al. (2012) use data from urban Ghana and find that those self-employed with at least one employee are significantly more happy and satisfied with their work than those working for a wage in the formal sector. 
Standards Survey (VHLSS) in the 12 provinces. $^{6}$ To ensure proportionate representation of households that have come into existence after 2004 and replace households that could not be re-interviewed, 544 additional households were sampled (drawn from the list of households available from the 2009 Population Census). Provinces were selected to facilitate the use of the survey as an evaluation tool for Danida-supported development programs in Vietnam. ${ }^{7}$ Seven of the 12 provinces are covered by the Danida Business Sector Program Support and five provinces by the Agricultural and Rural Development (ARD) program. The provinces supported by ARD are located in the north-west and central highlands, so these relatively poor and sparsely populated regions are somewhat over-represented in the sample, relative to the Vietnamese population. The survey is statistically representative of rural households at province level.

The measure of happiness collected in VARHS is a single-item measure of life evaluation. In particular, it asks: 'taking all things together, would you say you are: (1) very pleased with your life; (2) rather pleased with your life; (3) not very pleased with your life; (4) Not at all pleased with your life'; and respondents choose one answer. A strong advantage of the single-item approach, as opposed to multiple-item measures, where respondents state their satisfaction with life in several different domains (work, marriage etc.), is reduced cultural sensitivity (Veenhoven 1984). The importance of being satisfied with life domains such as work or marriage may vary greatly across cultures and over time, implying that the appropriate weights for different items also vary.

The question on subjective well-being was only answered by one respondent in each household, typically the household head. Accordingly, our sample is not representative at the individual level. On the other hand, there are important benefits from using household survey data. In particular, the survey collects detailed data on a number of individual- and household level characteristics, including income, occupation, health, education, social networks, migration, and so on. This information is much more detailed than in surveys such as the Gallup World Poll and the World Values Survey (WVS), which have been used in many studies of happiness (e.g. Helliwell et al. 2012; Deaton 2008).

\section{Analytical Model and Variables}

Our main purpose is to investigate the effect of employment category on subjective wellbeing. We run regression models of the following type:

$$
H_{i}=S_{i}^{\prime} \beta+X_{i}^{\prime} \gamma+p_{i}^{\prime} \lambda+\varepsilon_{i}
$$

where $H_{i}$ is the answer of respondent $i$ to the subjective well-being question described above; $S_{i}$ is a vector of indicators for employment category; $X_{i}$ is a vector of other variables that may affect subjective well-being; $p_{i}$ is a dummy for province of residence; and $\varepsilon_{i}$ is the error term. Errors are allowed to be correlated within communes (the primary sampling unit), but not across. $\beta, \gamma$, and $\lambda$ are vectors of coefficients to be estimated.

\footnotetext{
${ }^{6}$ See CIEM et al. (2013) for further information. The sampled provinces are, by region: Red River Delta: Ha Tay. North-east: Lao Cai, Phu Tho. North-west: Lai Chau, Dien Bien. North Central Coast: Nghe Anh. South Central Coast: Quang Nam, Khanh Hoa. Central Highlands: Dak Lak, Dak Nong, Lam Dong. Mekong River Delta: Long An.

${ }^{7}$ Respondent were not informed that the survey was sponsored by Danida or that it was aimed at evaluating a program. Survey implementation followed standard procedures.
} 
In terms of employment category, we distinguish between self-employment, wage work, and no employment. The vast majority in the last category are either too old or too sick to work. Only very few are 'unemployed' in the sense of desiring a job without being able to find one. We distinguish between self-employment in farming, in non-farm enterprises, and in collection of common property resources (CPRs) ${ }^{8}$ Classification is based on respondents' 'main' source of employment, defined as the occupation they spend most time in. Because the main aim of the analysis is to identify the difference in happiness between self-employed and wage workers, respondents with no employment are excluded from the estimation sample.

Figure 1 presents the analytical model used to select the elements of $X_{i}$, the control variables in the regressions. We distinguish between two types of variables. 'Background variables' are exogenous to employment. These variables may affect employment and could also directly drive happiness. 'Intermediate variables', on the other hand, are potentially affected by employment and therefore may mediate a causal effect from employment to happiness. Controlling for background variables allows us to identify the total, causal effect of employment category on happiness, including indirect effects that operate through income, risk exposure, social networks, and so on. However, the hypotheses derived in Sect. 2 concern the direct effect of employment category on autonomy, competence and relatedness and therefore on subjective well-being. Testing these hypotheses requires that intermediate variables such as income are controlled for.

Our main purpose is therefore to estimate models where both background- and intermediate variables are controlled, but estimates of the total (direct plus indirect) effect are also of interest.

Background variables include age, gender, ethnicity, place of birth (commune of current residence or elsewhere), and years schooling. All other control variables are viewed as 'intermediate'. Among these variables, we first include a measure of income, measured at the household level. While a positive correlation between income and happiness is a standard finding in individual level analyses of happiness, it has been hotly debated whether this correlation is driven by absolute or relative income (e.g. Easterlin 1974; Cummins 2000; Berry 2009).

We also control for landlessness. In agriculture-based societies, such as rural Vietnam, land is a key source of income, risk coping, prestige, and identity. Two different measures of health, namely (a) the number of days in the last year the respondent was unable to perform normal activities due to illness, and (b) an indicator for the respondent's household being hit by any health shocks that led to income losses in the past 2 years are also included. Controls for the number of children in the household below 15 years of age and indicators for marital status are also used.

We include two measures of migration, in addition to the place of birth-indicator mentioned above, namely (a) an indicator for a member of the household having migrated temporarily (and currently being away), and (b) an indicator for former household

\footnotetext{
${ }^{8}$ A minority of non-farm enterprises (about 5\%) trade in agricultural products and in this sense belongs to the agricultural sector. Therefore, self-employment in farming (working on one's own family farm) is not entirely equivalent to self-employment in agriculture, which includes non-farm enterprises trading in agricultural products. We focus on the former category. It might be considered to group farmers and CPR collectors together. However, CPR collection is essentially 'hunting and gathering', historically a fundamentally different livelihood strategy than farming. Operating a farm typically implies considerably higher social recognition and economic security than relying on common property resources. We therefore keep the two categories apart.
} 


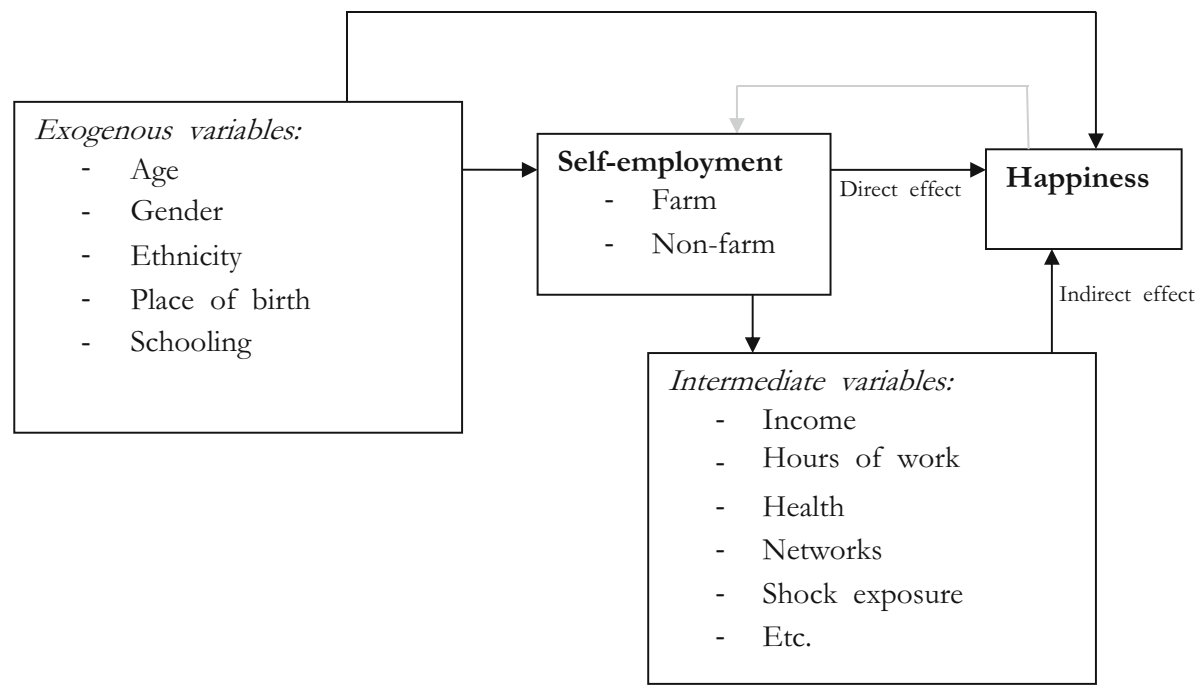

Fig. 1 Analytical model

members having permanently migrated to another commune, district or province (see De Jong et al. 2002; Knight and Gunatilaka 2010b).

Measures of social networks are also used (see Powdthavee 2008; Berry and Hansen, 1996). We distinguish between membership of the Communist Party, 'mass organizations', and other formal groups. Mass organizations are the most important type of formal group in Vietnam and include the Women's, Farmers', Youth, and Veterans' Unions. To proxy the strength of respondents' informal social networks, we use a measure of the number of weddings the respondent's household has attended in the past year.

We include dummies indicating whether the respondent's household experienced any of five different types of shocks in the past 2 years. The five types of shocks are (a) health shocks (already discussed above), (b) natural disasters, (c) pest infections and crop disease, (d) 'economic shocks' (price changes, unemployment, failure of an investment, and land loss), and (e) a residual category. Finally we include an indicator for being the household head due to the composition of the sample where household heads are over-represented.

\subsection{Endogeneity}

The purpose of these analyses is to investigate the effects of employment category on subjective well-being. In some cases it is relevant to speculate that causality may also run in the other direction (the grey arrow from happiness to employment in Fig. 1). For example, people with a positive outlook may be more likely than others to start their own business. Blanchflower and Oswald (1998) investigate the influence of a range of exogenous, psychological characteristics (measured in childhood) on the probability of becoming self-employed and find only weak effects. This suggests that the effect of happiness on self-employment may also be weak. Nevertheless, to take account of the possibility of a reverse link from happiness to self-employment, we implement an instrumental variables analysis, where self-employment is instrumented by commune level characteristics, which are exogenous to the psychological characteristics of respondents. 


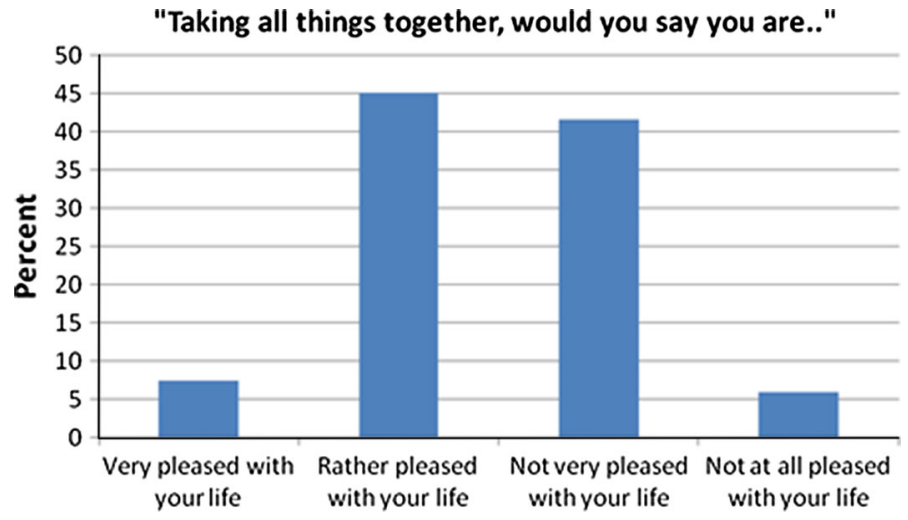

Fig. 2 Subjective well-being in rural Vietnam

The set of instruments, measured in a questionnaire administered to commune officials, includes (a) the commune level share of self-employment in total employment, (b) wage rates for two common wage jobs (harvesting and construction), separately for males and females, and (c) a dummy for the presence of 'craft villages' (villages with a tradition for a particular craft, e.g. basket weaving or pottery). The ideas behind this strategy are that (1) the probability of being self-employed depends on the overall prevalence of self-employment in one's area of residence, (2) higher wages provide an incentive to take up wage work, and (3) craft villages provide additional opportunities for self-employment.

In the instrumental variables (two-stage least squares) analysis the first-stage regression is a linear probability model for self-employment:

$$
s_{i}=Z_{c}^{\prime} \delta+X_{i}^{\prime} \theta+p_{i}^{\prime} \eta+\mu_{i}
$$

where $s_{i}$ is a dummy for being self-employed, $Z_{i}$ is the vector of commune-level instruments described above, and $X_{i}$ and $p_{i}$ are defined as in Eq. (1). $\delta, \theta$ and $\eta$ are parameters to be estimated. The second-stage regression is:

$$
H_{i}=\beta_{I V} \hat{s}_{i}+X_{i}^{\prime} \gamma_{I V}+p_{i}^{\prime} \lambda_{I V}+\varepsilon_{I V i}
$$

where $\hat{s}_{i}$ is the predicted value of $s_{i}$ from the first stage regression and other variables are defined as in Eq. (1). The subscript "IV" indicates that estimates are from the IV analysis. Table 2 presents the means and medians of the instrumental variables. ${ }^{9}$

\section{Descriptive Statistics}

Figure 2 presents the distribution of answers to the subjective well-being question described in Sect. 3. There is significant variation across respondents. A total of $52 \%$ are 'very' or 'rather' pleased, while $48 \%$ are 'not very' or 'not at all' pleased with their lives. The share falling in the last two categories is large and may be viewed as a cause for

\footnotetext{
9 A comparison of Tables 1 and 2 shows that the estimated rate of self-employment is higher in the commune data set (Table 2) than in the individual level data (Table 1). One reason may be that commune officials underestimate the importance of wage work, but another explanation is that wage workers are somewhat overrepresented in the individual level data set.
} 
Table 1 Descriptive statistics and bivariate correlations with subjective well-being

\begin{tabular}{|c|c|c|c|c|}
\hline \multirow[t]{2}{*}{ Variable } & \multirow[t]{2}{*}{ Mean } & \multirow[t]{2}{*}{ Median } & \multicolumn{2}{|c|}{ Share 'rather' or 'very' pleased with life } \\
\hline & & & $\begin{array}{l}\text { Low value on row } \\
\text { variable }\end{array}$ & $\begin{array}{l}\text { High value on row } \\
\text { variable }\end{array}$ \\
\hline \multicolumn{5}{|l|}{ Main occupation } \\
\hline Wage worker & 0.24 & & 0.53 & 0.51 \\
\hline Self-employed, agriculture & 0.49 & & 0.53 & 0.52 \\
\hline Self-employed, non-farm enterprise & 0.13 & & 0.52 & $0.59 * *$ \\
\hline $\begin{array}{l}\text { Self-employed, common property } \\
\text { resources }\end{array}$ & 0.02 & & 0.53 & 0.42 \\
\hline None & 0.13 & & 0.53 & 0.52 \\
\hline Income per capita, '000 VND & 13,273 & 9640 & 0.41 & $0.63 * * *$ \\
\hline $\begin{array}{l}\text { Median commune income, } \\
\text { '000 VND }\end{array}$ & 11,034 & 10,339 & 0.49 & $0.56 * * *$ \\
\hline Days worked in last year & 156 & 150 & 0.52 & 0.54 \\
\hline Landless & 0.09 & & 0.52 & 0.53 \\
\hline Female & 0.33 & & 0.54 & $0.49 * *$ \\
\hline Age & 49.8 & 49 & 0.52 & 0.53 \\
\hline Years of schooling & 7.1 & 8 & 0.48 & $0.58 * * *$ \\
\hline Children below 15 & 1.02 & 1 & 0.53 & 0.51 \\
\hline Kinh & 0.79 & & 0.43 & $0.55 * * *$ \\
\hline \multicolumn{5}{|l|}{ Marital status } \\
\hline Married & 0.82 & & 0.43 & $0.55 * * *$ \\
\hline Never married & 0.03 & & 0.53 & 0.46 \\
\hline Widowed & 0.13 & & 0.54 & $0.44 * * *$ \\
\hline Divorced or separated & 0.02 & & 0.53 & $0.31 * * *$ \\
\hline Member of Communist Party & 0.06 & & 0.51 & $0.75 * * *$ \\
\hline Member of mass organization & 0.55 & & 0.50 & $0.55^{*}$ \\
\hline Member of other formal group & 0.19 & & 0.52 & 0.55 \\
\hline Weddings attended & 16.9 & 15 & 0.49 & $0.57 * * *$ \\
\hline \multicolumn{5}{|l|}{ Shocks to $\mathrm{HH}$ in last 2 years } \\
\hline Natural disaster & 0.09 & & 0.53 & $0.46^{*}$ \\
\hline $\begin{array}{l}\text { Pest infection, crop disease or } \\
\text { avian flu }\end{array}$ & 0.23 & & 0.55 & $0.45 * * *$ \\
\hline $\begin{array}{l}\text { Economic (unemployment, loss } \\
\text { of land etc.) }\end{array}$ & 0.07 & & 0.53 & $0.47 *$ \\
\hline Illness & 0.11 & & 0.54 & $0.41 * * *$ \\
\hline Other shock & 0.02 & & 0.53 & 0.53 \\
\hline $\begin{array}{l}\text { Work days lost due to illness } \\
\text { in last year }\end{array}$ & 12.2 & 0 & 0.57 & $0.49 * * *$ \\
\hline $\mathrm{HH}$ head born in commune & 0.70 & & 0.52 & 0.53 \\
\hline HH member migrated permanently & 0.08 & & 0.52 & 0.53 \\
\hline $\mathrm{HH}$ member migrated temporarily & 0.09 & & 0.52 & $0.62^{* * *}$ \\
\hline
\end{tabular}


Table 1 continued

\begin{tabular}{llll}
\hline Variable & Mean & Median & \begin{tabular}{l} 
Share 'rather' or 'very' pleased with life \\
\cline { 3 - 4 }
\end{tabular} \\
\hline Head & 0.80 & $\begin{array}{l}\text { Low value on row } \\
\text { variable }\end{array}$ & $\begin{array}{l}\text { High value on row } \\
\text { variable }\end{array}$ \\
\hline
\end{tabular}

$\mathrm{N}=2740$. In the last two columns, entries are share of respondents who are 'rather' or 'very' pleased with life. The column heading 'Low (high) on row variable' means zero (one) on dummy variables and below (above) median on continuous variables. Stars indicate whether the difference in subjective well-being between the two groups is statistically significant

* Significant at $10 \%$

** Significant at $5 \%$

*** Significant at $1 \%$

Table 2 Instrumental variables

\begin{tabular}{lcc}
\hline & Mean & Median \\
\hline Share of workforce self-employed $(\%)$ & 89.3 & 93.0 \\
Male wage rate in harvesting & 134.0 & 120.0 \\
Female wage rate in harvesting & 121.1 & 120.0 \\
male wage rate in construction & 158.6 & 150.0 \\
Female wage rate in construction & 131.6 & 120.0 \\
Presence of craft village $(\%)$ & 24.9 & - \\
\hline
\end{tabular}

Commune level results. $\mathrm{N}=470$. Wage rates in ' $000 \mathrm{VND}$ per day

concern. ${ }^{10}$ Our questions and sampling are somewhat different from other surveys, so comparison of the measured level of happiness measured is not trivial. We therefore focus on the explanations for the observed variation.

Table 1 presents descriptive statistics on the explanatory variables discussed above, and on subjective well-being. The first column shows the mean of each variable. The second column shows medians for non-dummy variables. The last two columns, with the headings 'low value on row variable' and 'high value on row variable' show the share of respondents, who are either 'very' or 'rather' pleased with their lives, separately for respondents with high and low values on the row variables. For dummy variables, 'low' is zero and 'high' one. For other variables, 'low' is at or below the median value, whereas 'high' is above the median. For example, the sixth row (income per capita) shows that $41 \%$ of those with below-median income, and $63 \%$ of those above the median, are rather or very pleased with life.

The table does not reveal strong effects of employment category. The happiest respondents are those self-employed in non-farm enterprises. The tables in what follows show that results change very significantly when these factors are controlled for.

${ }^{10}$ In the World Values Survey in Vietnam (pooled results for 2001, 2006) $92 \%$ of respondents report being 'very' or 'quite' happy, while only $8 \%$ are 'not very' or 'not at all' happy. 


\section{Regression Analysis of Self-Employment and Happiness}

Table 3 presents regressions for happiness. The dependent variable is the four-category subjective well-being measure described in Sect. 3 and Fig. 2. The measure is an ordinal scale variable. Therefore, we estimate ordered probit regressions (except regression 5). Standard errors are adjusted for commune level clustering. All regressions include province dummies (not shown). Results with commune fixed effects are remarkably similar (see Markussen et al. 2014).

Consider first the respondent's type of employment. The reference category is wage work. Regressions 1, 3, and 5 include a dummy for self-employment, while regressions 2 and 4 sub-divide the self-employed into the three sectors discussed above: own farm, nonfarm enterprises, and CPR collection. In addition to the employment indicators, regressions 1 and 2 include background variables and province dummies, while regressions 3 and 4 include background and intermediate variables as well as province dummies. Regression 5 is an instrumental variables model, discussed below. Pseudo log-likelihood and pseudo R-squared values confirm that control variables increase the explanatory power of the model substantially. Linktests in all cases fail to reject the hypothesis that the model is correctly specified (the table displays the $p$ value for the $\hat{y}^{2}$-term, the key element of the linktest).

Regressions 1 and 3 both show a statistically significant, positive effect of self-employment, similar to the results from Western countries already discussed. The effect is stronger in model 3, which controls for intermediate variables, than in model 1, which does not. This reflects the negative correlations between self-employment and some of the intermediate factors with a positive effect on happiness, such as income and Communist Party membership. In other words, the indirect effects of self-employment on happiness are negative.

Regression 2 shows statistically significant, positive effects of self-employment in both farm- and non-farm enterprises. Self-employment in CPR collection is positive, but statistically insignificant. Importantly, regression 4 reveals that the direct effect of self-employment on happiness (i.e. the effect that does not operate through income or other factors) is largely driven by self-employment in farming. The indirect effects of selfemployment appear to be negative for farm- and positive for non-farm enterprises. This reflects, among other things, the fact that average income is higher for wage laborers than for those self-employed in farming, and lower than for those operating non-farm enterprises. ${ }^{11}$ The large difference between the effects of self-employment in farming and in non-farm enterprises suggests that in the context of rural Vietnam, the psychological effect of self-employment is not driven by autonomy per se, as suggested by Benz and Frey (2008a, b), but by autonomy in a particular environment, namely that of the family farm. The results are consistent with the theoretical discussion in Sect. 2, which suggested that working on a family farm may increase feelings of competence and relatedness, as well as autonomy, and therefore enhance subjective well-being.

Regression 5 presents the results of an instrumental variables (IV) analysis where selfemployment is instrumented by commune level self-employment, wage rates, and the presence of craft villages (see Sect. 4). We are not aware of methods to deal with endogenous regressors in the ordered probit model and therefore estimate a two-stage least

\footnotetext{
11 Median, annual income per capita is 7.8 million VND for self-employed farmers, 7.9 million VND for those self-employed in CPR collection, 10.2 million VND for wage workers, and 14.6 million VND for those self-employed in non-farm enterprises.
} 
Table 3 Subjective well-being regressions

Dependent variable: subjective well-being (four categories)

\begin{tabular}{lllll}
\hline O- & O- & O- & O- & 2SLS \\
PROBIT & PROBIT & PROBIT & PROBIT & \\
$(1)$ & $(2)$ & $(3)$ & $(4)$ & $(5)$ \\
\hline
\end{tabular}

Main type of employment (ref. cat.: Wage worker)

\begin{tabular}{|c|c|c|c|c|c|}
\hline Self-employed & $\begin{array}{l}0.187 * * * \\
(0.052)\end{array}$ & & $\begin{array}{l}0.264 * * * \\
(0.057)\end{array}$ & & $\begin{array}{l}0.949 * \\
(0.538)\end{array}$ \\
\hline Self-employed on own farm & & $\begin{array}{l}0.177 * * * \\
(0.055)\end{array}$ & & $\begin{array}{l}0.355 * * * \\
(0.064)\end{array}$ & \\
\hline Self-employed in non-farm enterprise & & $\begin{array}{l}0.227 * * * \\
(0.080)\end{array}$ & & $\begin{array}{l}0.113 \\
(0.086)\end{array}$ & \\
\hline Self-employed in CPR collection & & $\begin{array}{l}0.04 \\
(0.170)\end{array}$ & & $\begin{array}{l}0.204 \\
(0.171)\end{array}$ & \\
\hline Female & $\begin{array}{l}-0.122 * * \\
(0.051)\end{array}$ & $\begin{array}{l}-0.124 * * \\
(0.051)\end{array}$ & $\begin{array}{l}-0.071 \\
(0.081)\end{array}$ & $\begin{array}{l}-0.064 \\
(0.082)\end{array}$ & $\begin{array}{l}-0.096 \\
(0.064)\end{array}$ \\
\hline Age in year & $\begin{array}{l}-0.013 \\
(0.011)\end{array}$ & $\begin{array}{l}-0.014 \\
(0.011)\end{array}$ & $\begin{array}{l}-0.039 * * * \\
(0.013)\end{array}$ & $\begin{array}{l}-0.041^{* * *} \\
(0.013)\end{array}$ & $\begin{array}{l}-0.034 * * * \\
(0.011)\end{array}$ \\
\hline Age squared $* 10^{-3}$ & $\begin{array}{l}0.156 \\
(0.104)\end{array}$ & $\begin{array}{l}0.164 \\
(0.104)\end{array}$ & $\begin{array}{l}0.438 * * * \\
(0.127)\end{array}$ & $\begin{array}{l}0.458 * * * \\
(0.126)\end{array}$ & $\begin{array}{l}0.315 * * * \\
(0.095)\end{array}$ \\
\hline $\mathrm{HH}$ is Kinh & $\begin{array}{l}0.025 \\
(0.105)\end{array}$ & $\begin{array}{l}0.018 \\
(0.106)\end{array}$ & $\begin{array}{l}-0.101 \\
(0.119)\end{array}$ & $\begin{array}{l}-0.085 \\
(0.121)\end{array}$ & $\begin{array}{l}-0.033 \\
(0.080)\end{array}$ \\
\hline Years of schooling, $\ln (x+1)$ & $\begin{array}{l}0.262 * * * \\
(0.042)\end{array}$ & $\begin{array}{l}0.258 * * * \\
(0.042)\end{array}$ & $\begin{array}{l}0.112 * * \\
(0.045)\end{array}$ & $\begin{array}{l}0.113 * * \\
(0.045)\end{array}$ & $\begin{array}{l}0.085 * * \\
(0.035)\end{array}$ \\
\hline Head born in commune & $\begin{array}{l}0.139 * * \\
(0.060)\end{array}$ & $\begin{array}{l}0.139 * * \\
(0.060)\end{array}$ & $\begin{array}{l}0.132 * * \\
(0.061)\end{array}$ & $\begin{array}{l}0.141 * * \\
(0.060)\end{array}$ & $\begin{array}{l}0.126 * * \\
(0.049)\end{array}$ \\
\hline Income per $\mathrm{HH}$ member, log & & & $\begin{array}{l}0.359 * * * \\
(0.045)\end{array}$ & $\begin{array}{l}0.380 * * * \\
(0.045)\end{array}$ & $\begin{array}{l}0.150 * * * \\
(0.041)\end{array}$ \\
\hline Days worked, $\ln (x+1)$ & & & $\begin{array}{l}-0.002 \\
(0.043)\end{array}$ & $\begin{array}{l}0.033 \\
(0.047)\end{array}$ & $\begin{array}{l}0.13 \\
(0.094)\end{array}$ \\
\hline Landless & & & $\begin{array}{l}-0.013 \\
(0.095)\end{array}$ & $\begin{array}{l}0.038 \\
(0.096)\end{array}$ & $\begin{array}{l}0.084 \\
(0.102)\end{array}$ \\
\hline Children below $15, \ln (x+1)$ & & & $\begin{array}{l}0.043 \\
(0.054)\end{array}$ & $\begin{array}{l}0.060 \\
(0.054)\end{array}$ & $\begin{array}{l}0.005 \\
(0.036)\end{array}$ \\
\hline \multicolumn{6}{|l|}{ Marital status } \\
\hline Never married & & & $\begin{array}{l}-0.174 \\
(0.144)\end{array}$ & $\begin{array}{l}-0.169 \\
(0.143)\end{array}$ & $\begin{array}{l}-0.108 \\
(0.110)\end{array}$ \\
\hline Widowed & & & $\begin{array}{l}-0.186^{*} \\
(0.107)\end{array}$ & $\begin{array}{l}-0.189 * \\
(0.107)\end{array}$ & $\begin{array}{l}-0.079 \\
(0.072)\end{array}$ \\
\hline Divorced or separated & & & $\begin{array}{l}-0.603^{* * * *} \\
(0.212)\end{array}$ & $\begin{array}{l}-0.594 * * * \\
(0.212)\end{array}$ & $\begin{array}{l}-0.258^{*} \\
(0.151)\end{array}$ \\
\hline Member of Communist Party & & & $\begin{array}{l}0.569 * * * \\
(0.115)\end{array}$ & $\begin{array}{l}0.560 * * * \\
(0.114)\end{array}$ & $\begin{array}{l}0.562 * * * \\
(0.147)\end{array}$ \\
\hline Member of mass organization & & & $\begin{array}{l}0.195 * * * \\
(0.062)\end{array}$ & $\begin{array}{l}0.181 * * * \\
(0.063)\end{array}$ & $\begin{array}{l}0.115^{* * * *} \\
(0.043)\end{array}$ \\
\hline $\begin{array}{l}\text { Member of group other than party, } \\
\text { mass org }\end{array}$ & & & $\begin{array}{l}0.102 \\
(0.091)\end{array}$ & $\begin{array}{l}0.095 \\
(0.092)\end{array}$ & $\begin{array}{l}0.066 \\
(0.058)\end{array}$ \\
\hline $\begin{array}{l}\text { Weddings attended in other } \mathrm{HH} \text {, } \\
\log (\mathrm{x}+1)\end{array}$ & & & $\begin{array}{l}0.139 * * * \\
(0.041)\end{array}$ & $\begin{array}{l}0.139 * * * \\
(0.042)\end{array}$ & $\begin{array}{l}0.095 * * * \\
(0.030)\end{array}$ \\
\hline
\end{tabular}


Table 3 continued

\begin{tabular}{|c|c|c|c|c|c|}
\hline & \multicolumn{5}{|c|}{ Dependent variable: subjective well-being (four categories) } \\
\hline & $\begin{array}{l}\text { O- } \\
\text { PROBIT } \\
(1)\end{array}$ & $\begin{array}{l}\text { O- } \\
\text { PROBIT } \\
(2)\end{array}$ & $\begin{array}{l}\text { O- } \\
\text { PROBIT } \\
(3)\end{array}$ & $\begin{array}{l}\text { O- } \\
\text { PROBIT } \\
(4)\end{array}$ & $\begin{array}{l}\text { 2SLS } \\
(5)\end{array}$ \\
\hline Natural disaster & & & $\begin{array}{l}0.019 \\
(0.086)\end{array}$ & $\begin{array}{l}0.01 \\
(0.087)\end{array}$ & $\begin{array}{l}-0.033 \\
(0.072)\end{array}$ \\
\hline Pest infection, crop disease or avian flu & & & $\begin{array}{l}-0.042 \\
(0.061)\end{array}$ & $\begin{array}{l}-0.055 \\
(0.061)\end{array}$ & $\begin{array}{l}-0.105^{*} \\
(0.055)\end{array}$ \\
\hline $\begin{array}{l}\text { Economic (unemployment, loss of land } \\
\text { etc.) }\end{array}$ & & & $\begin{array}{l}-0.261^{* * * *} \\
(0.098)\end{array}$ & $\begin{array}{l}-0.267 * * * \\
(0.097)\end{array}$ & $\begin{array}{l}-0.171^{* *} \\
(0.074)\end{array}$ \\
\hline Illness & & & $\begin{array}{l}-0.347 * * * \\
(0.091)\end{array}$ & $\begin{array}{l}-0.346^{* * * *} \\
(0.091)\end{array}$ & $\begin{array}{l}-0.137 * * \\
(0.062)\end{array}$ \\
\hline Other shock & & & $\begin{array}{l}0.062 \\
(0.229)\end{array}$ & $\begin{array}{l}0.078 \\
(0.229)\end{array}$ & $\begin{array}{l}-0.001 \\
(0.167)\end{array}$ \\
\hline $\begin{array}{l}\text { Days unable to work due to illness in } \\
\text { last year, } \log (x+1)\end{array}$ & & & $\begin{array}{l}-0.080 * * * \\
(0.022)\end{array}$ & $\begin{array}{l}-0.082^{* * * *} \\
(0.022)\end{array}$ & $\begin{array}{l}-0.052^{* * *} \\
(0.014)\end{array}$ \\
\hline HH member migrated permanently & & & $\begin{array}{l}-0.041 \\
(0.077)\end{array}$ & $\begin{array}{l}-0.045 \\
(0.077)\end{array}$ & $\begin{array}{l}-0.059 \\
(0.062)\end{array}$ \\
\hline $\mathrm{HH}$ member migrated temporarily & & & $\begin{array}{l}0.133 \\
(0.082)\end{array}$ & $\begin{array}{l}0.134 \\
(0.082)\end{array}$ & $\begin{array}{l}0.094 \\
(0.058)\end{array}$ \\
\hline HH head & & & $\begin{array}{l}-0.069 \\
(0.099)\end{array}$ & $\begin{array}{l}-0.067 \\
(0.100)\end{array}$ & $\begin{array}{l}0.015 \\
(0.075)\end{array}$ \\
\hline Province dummies & Yes & Yes & Yes & Yes & Yes \\
\hline Observations & 2322 & 2322 & 2202 & 2202 & 1915 \\
\hline $\begin{array}{l}\text { Wald test of model significance Chi } \\
\text { squared value, } p \text { val. in par. }\end{array}$ & $\begin{array}{l}157.1 \\
(0.00)\end{array}$ & $\begin{array}{l}157.5 \\
(0.00)\end{array}$ & $\begin{array}{l}379.2 \\
(0.00)\end{array}$ & $\begin{array}{l}418.2 \\
(0.00)\end{array}$ & \\
\hline Pseudo log-likelihood & -2425.5 & -2424.9 & -2157.7 & -2153.3 & \\
\hline Pseudo R-squared & 0.034 & 0.034 & 0.091 & 0.093 & \\
\hline Linktest ( $p$ value of $\hat{y}^{2}$ ) & 0.815 & 0.665 & 0.159 & 0.157 & 0.658 \\
\hline $\begin{array}{l}\text { Chi squared test of endogeneity of self- } \\
\text { employment }\end{array}$ & & & & & $1.48(.22)$ \\
\hline $\begin{array}{l}\text { Kleibergen-Paap rk LM statistic } \\
\quad \text { (underidentification, } p \text { value in par.) }\end{array}$ & & & & & $11.87(.06)$ \\
\hline $\begin{array}{l}\text { Kleibergen-Paap rk F statistic (weak } \\
\text { identification) }\end{array}$ & & & & & $2.17(.04)$ \\
\hline $\begin{array}{l}\text { Hansen } \mathrm{J} \text { statistics (overidentification, } \\
\quad p \text { value in par.) }\end{array}$ & & & & & $6.96(.22)$ \\
\hline
\end{tabular}

Regressions 1-4 are ordered probits. Regression 5 is a 2 SLS with self-employed instrumented by the commune level rate of self-employment, male and female wage rates in harvesting and construction, and a dummy for the presence of craft villages in the commune. Only employed respondents included. Standard errors (in parentheses) adjusted for clustering at the village level

* Significant at $10 \%$

** Significant at $5 \%$

*** Significant at $1 \%$

squares regression. The bottom lines of the table present tests for endogeneity of selfemployment, and for instrument quality. First, a Chi squared test of endogeneity does not reject the null-hypothesis that self-employment is exogenous. This should increase 
Table 4 Sector of occupation, wage workers

\begin{tabular}{lr}
\hline Sector & Percent \\
\hline Agriculture & 16.5 \\
Mining & 1.1 \\
Manufacturing & 16.8 \\
Construction & 29.5 \\
Services & 36.1 \\
\hline
\end{tabular}

$\mathrm{N}=637$

confidence in the results from regressions 1-4, which treat self-employment as exogenous. While this makes the IV-results less interesting we nevertheless present them, noting that the power of the endogeneity test is limited. The Hansen $J$ test supports the assumption of instrument exogeneity. The Kleibergen-Paap $F$ statistic is useful for judging whether instruments are weak (Kleibergen and Paap 2006). The value of the F-statistic is only 2.2. Comparison with the critical values in Stock and Yogo (2005) suggests that the instruments are quite weak and that point estimates as well as inference may be biased. Consequently, the results in regression 5 should the treated with caution. Nevertheless, the fact that the estimated coefficient on self-employment remains positive and statistically significant does lend further support to the hypothesis of a causal effect from self-employment to happiness.

Tables 4 and 5 explore in more detail what drives the negative effect of working for a wage, relative to working on one's own family farm. Table 4 presents the distribution of wage workers across sectors, showing that services and construction are the largest sectors. Table 5 presents additional regression analyses. The regressions include the same control variables as in regressions 3-5 in Table 3 (estimates not reported). Note that the reference category for employment is now self-employment on own farm, rather than wage labor. This allows us to investigate the effects of different types of wage labor in detail.

The table first introduces interactions between employment categories and age. In the interaction terms, age is entered as deviation from mean age. The idea is that the negative effect of wage labor could be driven by older respondents, whose values, skills and social relations may be more closely linked with traditional, rural life than is the case for younger generations. The results give some support to this view-the negative effect of wage labor is stronger among the old than the young. However, the interaction term between wage labor and age is not significant $(p=.15)$ and, based on the point estimates, the effect of being a wage worker is negative among all adult age groups. On the other hand, the negative effect of working in own non-farm enterprises is only present among older respondents. The point estimates imply that the effect of being a non-farm enterprise operator, relative to working on a family farm, is only negative for a person older than 33 years.

Regression 2 investigates whether the negative effect of wage labor is transitory or permanent. The regression includes indicators for being a wage worker (a) now, (b) 2 years ago, and (c) both now and 2 years ago (similarly for self-employment in non-farm enterprise and CPR collection). The data on employment 2 years ago were collected in the 2010 wave of the VARHS survey. Data are therefore only available in those cases where the individual respondent, who answered the question on happiness in 2012, was also present in the household in $2010 .{ }^{12}$ Results show that the coefficient on current wage labor

12 Individual respondents are matched on age and gender. 
Table 5 Exploring effect of wage labor on subjective well-being

Dependent variable: subjective well-being (four categories)

\begin{tabular}{lllll}
\hline 1 & $(2)$ & (3) & (4)
\end{tabular}

Main type of employment (ref. Cat.: Self-empl on own farm)

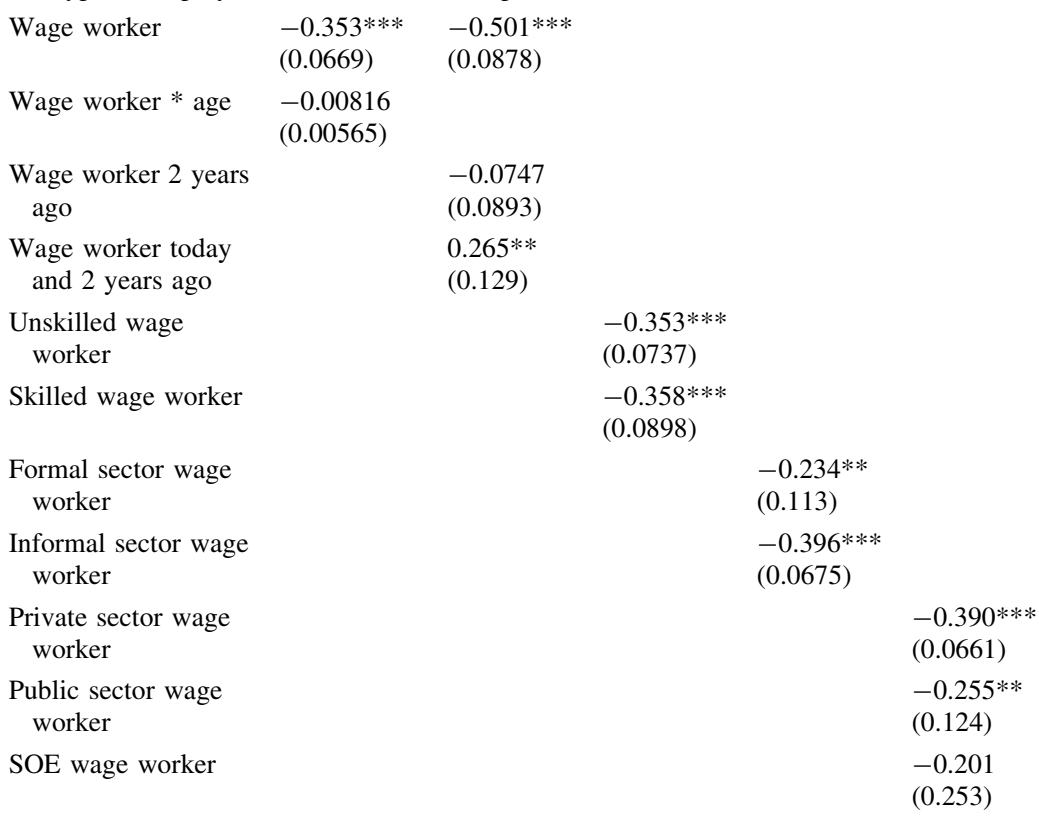

Wage worker in

Agriculture

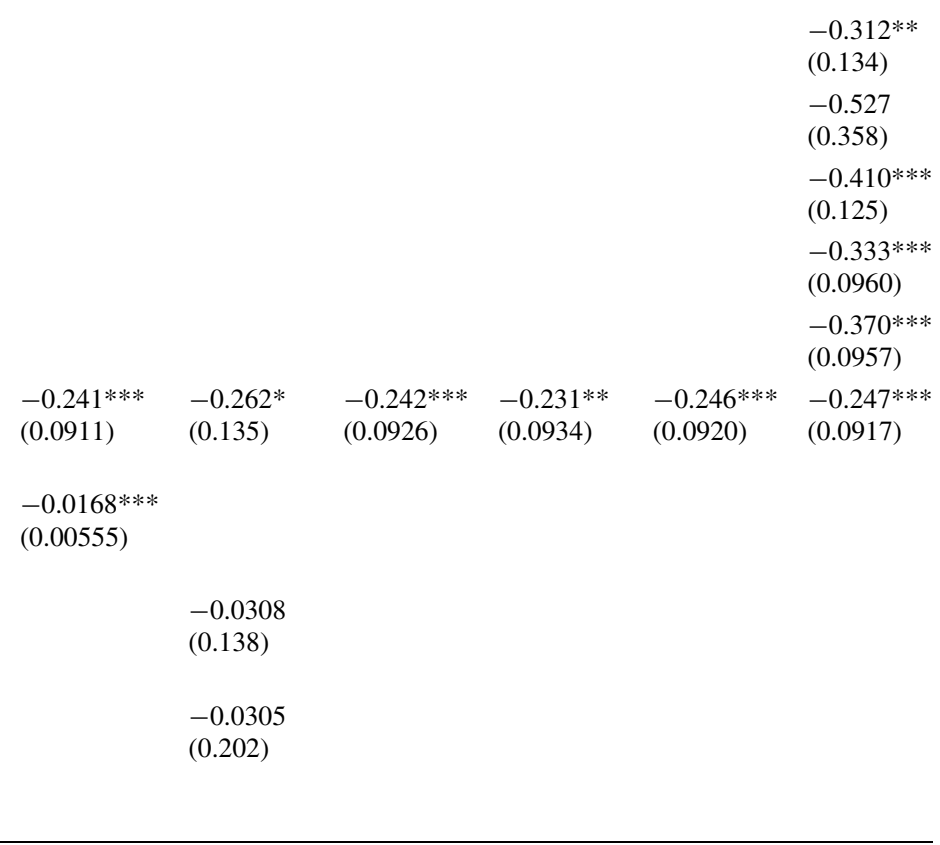


Table 5 continued

\begin{tabular}{|c|c|c|c|c|c|c|}
\hline & \multicolumn{6}{|c|}{ Dependent variable: subjective well-being (four categories) } \\
\hline & (1) & (2) & (3) & (4) & $(5)$ & (6) \\
\hline $\begin{array}{l}\text { Self-employed in } \\
\text { CPR collection }\end{array}$ & $\begin{array}{l}-0.0953 \\
(0.171)\end{array}$ & $\begin{array}{l}-0.371 \\
(0.263)\end{array}$ & $\begin{array}{l}-0.151 \\
(0.166)\end{array}$ & $\begin{array}{l}-0.154 \\
(0.167)\end{array}$ & $\begin{array}{l}-0.156 \\
(0.167)\end{array}$ & $\begin{array}{l}-0.150 \\
(0.166)\end{array}$ \\
\hline $\begin{array}{l}\text { Self-employed in } \\
\text { CPR } \\
\text { collection * age }\end{array}$ & $\begin{array}{l}-0.0123 \\
(0.00897)\end{array}$ & & & & & \\
\hline $\begin{array}{l}\text { Self-employed in } \\
\text { CPR coll. } 2 \text { years } \\
\text { ago }\end{array}$ & & $\begin{array}{l}0.190 \\
(0.314)\end{array}$ & & & & \\
\hline $\begin{array}{l}\text { Self-employed in } \\
\text { CPR coll. today } \\
\text { and } 2 \text { years ago }\end{array}$ & & $\begin{array}{l}0.606 \\
(0.548)\end{array}$ & & & & \\
\hline Province dummies & Yes & Yes & Yes & Yes & Yes & Yes \\
\hline Control variables & $\begin{array}{l}\text { As in } \\
\text { Table 3, } \\
\text { reg. } 3\end{array}$ & $\begin{array}{l}\text { As in } \\
\text { Table 3, } \\
\text { reg. } 3\end{array}$ & $\begin{array}{l}\text { As in } \\
\text { Table 3, } \\
\text { reg. } 3\end{array}$ & $\begin{array}{l}\text { As in } \\
\text { Table 3, } \\
\text { reg. } 3\end{array}$ & $\begin{array}{l}\text { As in } \\
\text { Table 3, } \\
\text { reg. } 3\end{array}$ & $\begin{array}{l}\text { As in } \\
\text { Table 3, } \\
\text { reg. 3 }\end{array}$ \\
\hline Observations & 2202 & 1681 & 2202 & 2202 & 2202 & 2202 \\
\hline $\begin{array}{l}\text { Wald test of model } \\
\text { significance Chi } \\
\text { squared value, } \\
p \text { val. in par. }\end{array}$ & $\begin{array}{l}422.5 \\
(0.00)\end{array}$ & $\begin{array}{l}427.6 \\
(0.00)\end{array}$ & $\begin{array}{l}420.3 \\
(0.00)\end{array}$ & $\begin{array}{l}419.2 \\
(0.00)\end{array}$ & $\begin{array}{l}420.0 \\
(0.00)\end{array}$ & $\begin{array}{l}423.7 \\
(0.00)\end{array}$ \\
\hline $\begin{array}{l}\text { Pseudo log- } \\
\text { likelihood }\end{array}$ & -2148.7 & -1630.8 & -2153.3 & -2152.2 & 2151.5 & -2153.0 \\
\hline Pseudo R-squared & 0.095 & 0.101 & 0.093 & 0.093 & 0.094 & 0.093 \\
\hline $\begin{array}{l}\text { Linktest ( } p \text { value of } \\
\hat{y}^{2} \text { ) }\end{array}$ & 0.151 & 0.262 & 0.157 & 0.135 & 0.184 & 0.149 \\
\hline
\end{tabular}

Ordered probit regressions. Standard errors (in parentheses) adjusted for clustering at the village level. Only employed respondents included. Regression 3 includes only observations with matched individual respondents in 2010 and 2012. In the interactions with age, age is included as deviation from mean age

* Significant at $10 \%$

** Significant at $5 \%$

*** Significant at $1 \%$

remains negative and statistically significant, while the coefficient on wage employment in both 2010 and 2012 is positive, with approximately half the numerical value of the coefficient on current wage work. In other words, the negative effect of wage labor is twice as high for those who turned to wage work recently (within the last 2 years) as for those who worked for a wage longer. This suggests that the effect of wage work is partly transitory. Yet, it takes more than 2 years to fully eliminate it.

Regressions 3-6 divide the wage-worker category into sub-categories. Regression 3 distinguishes between skilled and unskilled workers. Remarkably, the effects of these two types of wage work (again relative to working on own farm) are almost identical. Therefore, upgrading the educational level of the labor force may not necessarily eliminate the psychological cost of wage labor. Regression 4 splits the wage workers into formal and informal sectors. A 'formal job' is defined as one with a written labor contract (32\% of those classified as wage workers are in the formal sector). The estimated effects are significantly negative for both sectors. 
Table 6 Happiness and income

\begin{tabular}{|c|c|c|c|c|c|}
\hline & \multicolumn{5}{|c|}{ Dependent variable: subjective well-being (four categories) } \\
\hline & (1) & (2) & (3) & (4) & (5) \\
\hline $\begin{array}{l}\text { Income per HH member, } \\
\quad \log \end{array}$ & $\begin{array}{l}0.435 * * * \\
(0.0420)\end{array}$ & $\begin{array}{l}0.418 * * * \\
(0.0469)\end{array}$ & $\begin{array}{l}0.355 * * * \\
(0.0511)\end{array}$ & $\begin{array}{l}0.383 * * * \\
(0.0739)\end{array}$ & $\begin{array}{l}0.289 * * * \\
(0.0816)\end{array}$ \\
\hline $\begin{array}{l}\text { Median commune income } \\
\text { per capita, log }\end{array}$ & $\begin{array}{l}-0.132 * \\
(0.0750)\end{array}$ & $\begin{array}{l}-0.146^{*} \\
(0.0790)\end{array}$ & $\begin{array}{l}-0.170 * * \\
(0.0821)\end{array}$ & $\begin{array}{l}-0.376^{* *} \\
(0.174)\end{array}$ & $\begin{array}{l}-0.351 * * \\
(0.170)\end{array}$ \\
\hline $\begin{array}{l}\text { Income per HH member, } \\
\log , 2010\end{array}$ & & & $\begin{array}{l}0.145^{* * *} * \\
(0.0374)\end{array}$ & & $\begin{array}{l}0.213 * * * \\
(0.0615)\end{array}$ \\
\hline Province dummies & Yes & Yes & Yes & Yes & Yes \\
\hline Control variables & No & $\begin{array}{l}\text { As in Table 3, } \\
\text { reg. } 3\end{array}$ & $\begin{array}{l}\text { As in Table 3, } \\
\text { reg. } 3\end{array}$ & $\begin{array}{l}\text { As in Table 3, } \\
\text { reg. } 3\end{array}$ & $\begin{array}{l}\text { As in Table 3, } \\
\text { reg. } 3\end{array}$ \\
\hline Observations & 2202 & 2202 & 1727 & 817 & 716 \\
\hline $\begin{array}{l}\text { Wald test of model } \\
\text { significance }\end{array}$ & $\begin{array}{l}198.7 \\
(0.00)\end{array}$ & $\begin{array}{l}420.8 \\
(0.00)\end{array}$ & $\begin{array}{l}456.3 \\
(0.00)\end{array}$ & $\begin{array}{l}522.9 \\
(0.00)\end{array}$ & $\begin{array}{l}706.6 \\
(0.00)\end{array}$ \\
\hline $\begin{array}{l}\text { Chi squared value, } p \text { val. in } \\
\text { par. }\end{array}$ & & & & & \\
\hline Pseudo log-likelihood & -2246.4 & -2150.9 & -1691.8 & -810.3 & -699.7 \\
\hline Pseudo R-squared & 0.054 & 0.094 & 0.103 & 0.081 & 0.089 \\
\hline Linktest ( $p$ value of $\hat{y}^{2}$ ) & 0.915 & 0.130 & 0.055 & 0.661 & 0.049 \\
\hline
\end{tabular}

Ordered probit regressions. Standard errors (in parentheses) adjusted for clustering at the village level. Only employed respondents included. Regressions 3 and 5 include only households interviewed in both 2010 and 2012. Regressions 4 and 5 include only communes with at least 10 obs

* Significant at $10 \%$

** Significant at $5 \%$

*** Significant at $1 \%$

Regression 5 distinguishes between wage work in the public and private sectors, and in SOEs. The effects are negative for each sector, but the point estimate is higher for private sector work (the correlation between informal jobs and private sector jobs is quite high, $r=.70)$. Regression 6 splits the 'wage worker' category into sectors of occupation (agriculture, mining, manufacturing, construction, and services). The results for different sectors are remarkably similar. Accordingly, the negative effects of wage labor do not appear to be tied to agriculture. On the other hand, the statistically significant, negative effect on wage work in agriculture shows that it is not agriculture as such that drives happiness - it is working on one's own family farm that makes a significant difference. ${ }^{13}$

In general, Table 5 shows that the negative effect of wage labor is found across a broad range of jobs and among both young and old respondents; so the effect is unlikely to be driven by the characteristics of some types of particularly tough or low-status jobs. Rather, the negative effect of wage work appears to be accounted for by features shared by many types of jobs. One interpretation, based in self-determination theory, is that the key factor is a decrease in relatedness, rather than decreases in autonomy or competence. First, we would probably expect skilled workers to experience higher autonomy and competence than unskilled workers, yet the subjective well-being of these two groups is almost

\footnotetext{
${ }^{13}$ We could also split the self-employment in non-farm enterprise category into enterprises in different sectors. Since the number of respondents with non-farm enterprises is relatively small, it is difficult to estimate the separate effects of enterprises in different sectors precisely.
} 
identical (regression 3). Second, we argued above that many people in rural Vietnam may feel more competent in agriculture than in other sectors. However, this feeling should not depend on working on one's own farm, rather than someone else's. In contrast, regression 6 shows that people working on their own farms are happier than those working on other farms. One thing that does distinguish those employed on their own farm from agricultural laborers and from all other type of wage workers is that they are likely to be physically and mentally closer to their family members, including the elder generation. In this interpretation, the positive effect of self-employment in farming on subjective wellbeing is simply an effect of maintaining close ties to one's relatives.

\section{Results on Control Variables}

Many of the results on control variables are interesting in themselves, especially given the scarcity of happiness analyses in Vietnam and elsewhere in developing countries. We provide a brief overview and refer to Markussen et al. (2014) for further detail. The discussion refers to Table 3, unless otherwise stated.

\subsection{Gender}

The effect of being female is negative but only statistically significant in regressions 1 and 2 , where the point estimates are also substantially higher than in regressions 3-5. This suggests that the negative effect of being a woman to a large extent works through the additional variables added in regressions 3-5, such as income and marital status (in the case of married couples, the husband is often the questionnaire respondent). The negative effect of being a woman is consistent with other results from developing countries (Senik 2004; Graham and Pettinatto 2001).

\subsection{Age}

The effect of age is U-shaped in all regressions, although the coefficient estimates are only statistically significant in regressions $3-5$ (the trough is at 45 years in regression 4 ). The U-shaped relation is in line with findings in most studies on subjective well-being and age (Deaton 2008).

\subsection{Ethnicity}

In contrast with Table 1, the regressions in Table 3 show no statistically significant effect of belonging to the Kinh ethnicity. Consequently, the positive effect of being Kinh in Table 1 appears to be driven by differences in development outcomes, such as income and education, between ethnic minority and majority groups.

\subsection{Schooling}

There is a statistically significant, positive effect of years of schooling in all regressions. In the light of SDT, this might be regarded as an effect of increased autonomy and competence. 


\subsection{Income}

The effect of income is strong and statistically significant in all regressions that include this variable. This is consistent with results from a number of other countries, but does not reveal whether it is absolute or relative income that matters and whether the level of income is more important than the growth rate. To explore these issues, Table 6 presents regressions with additional, income related variables. In particular, median commune income (among the respondents in the sample from the same commune) and (in regressions 3 and 5) income in 2010 are included. Because the VARHS sample was expanded with 544 households in 2012, the reliance on 2010 data implies a drop in the number of observations. Results are therefore shown both with and without the 2010 income variable, in the latter case for the full 2012 sample. Median commune income is more precisely estimated when more households are sampled in a commune. The number of observations varies considerably across communes and to focus on communes with relatively precise estimates of median income, regressions 4 and 5 includes only communes with at least 10 observations. Regression 1 in Table 6 includes only province fixed effects, in addition to the income variables. The other regressions in the table include the same set of control variables as regression 4 in Table 3 , including self-employment dummies.

If respondents care about relative income, a negative effect of median commune income is expected, conditional on own income. The effect of income in the past is more difficult to predict. If consumption is determined by 'permanent income' (average lifetime income), and happiness is driven by consumption, then a positive effect is expected. On the other hand, it is also easy to imagine that the experience of progress is a source of happiness.

Results in Table 6 show a strong and highly, statistically significant, positive effect of own, current income, as in Tables 1 and 2. As expected, the effect of median commune income is negative, significant at the $10 \%$ level in regressions 1 and 2 and at the 5\% level in regressions 3, 4 and 5. In regression 4, where only communes with relatively precise measures of median income are included, the point estimate on median commune income is numerically almost equal to the coefficient on own income. The sum of the coefficients on own and commune income in this regression (and in regression 5) is not statistically significantly different from zero, implying that only relative, not absolute income matters and that general, economic growth has no direct impact on happiness.

The effect of income in 2010 is positive and statistically significant. This is consistent with the permanent income interpretation and inconsistent with the view that the experience of improvements in income is in itself a positive factor for happiness. ${ }^{14}$

\subsection{Landlessness}

We now return to Table 3. The coefficient on the dummy for landlessness is insignificant in all regressions, consistent with the argument in Ravallion and van de Walle (2008) that distress sales are not a major reason for loss of land in Vietnam.

\subsection{Health}

Both indicators of health (working days lost due to illness during the last year and health shocks to the respondent's household in the last 2 years) have statistically significant,

${ }^{14}$ Linktests reject the hypothesis that the models 3 and 5 are correctly specified, suggesting that the effect of income in 2010 might be non-linear. We do not pursue this issue further here. 
negative effects in regressions 3-5. This is consistent with a number of other studies on happiness and health (Helliwell et al. 2012).

\subsection{Marital Status}

Regressions 3-5 include a set of dummies for marital status. The reference category is 'married'. The results show negative effects of all categories, relative to being married. In particular, divorced or separated respondents (2\% of the sample) report much lower happiness than married respondents, consistent with most other results in the literature, and with the importance attached to family in Vietnamese culture, cf. the discussion above.

\subsection{Fertility}

The effect of children in the household is insignificant in all specifications. This is contrary to for example Kahnemann and Deaton (2010), who find that children in the household decreases subjective well-being.

\subsection{Social Networks}

There is a strong, positive and highly statistically significant effect of being a member of the Communist Party. Note that this also holds when income, type of occupation, health, and so on are controlled for. Thus, Party membership may matter for other than merely instrumental reasons. Being member of the Communist Party was also found to have a strong positive effect on subjective well-being in China by Knight and Gunatilaka (2010a) and Monk-Turner and Turner (2012). There is also a statistically significant and positive effect of mass organization membership, although the point estimate is much smaller than for party membership. The measure of informal networks, wedding attendance, is positive and statistically significant in all specifications.

\subsection{Migration}

Respondents in households with a 'migrant' background (i.e. where the head is not born in the commune of residence) are less happy than others, but there are no statistically significant effects of a household member having permanently or temporarily migrated to another commune.

\subsection{Headship}

No significant effects of being household head emerge. This reduces concerns about the effects of household heads being over-represented in the sample.

\subsection{Province}

After controlling for the variables discussed above, there are no strong province effects (results not shown). Respondents from Quang Nam and Lam Dong provinces are somewhat happier than the average, while those from Phu Tho and Nghe An are somewhat less happy. There are no clear patterns in terms of, for example, the north-south or highlandlowland dimensions, once other factors are controlled for. 


\section{Conclusions}

Focusing on rural Vietnam, this study documented a significant, positive effect on happiness from self-employment on family farms, relative to self-employment in non-farm enterprises and wage labor. The positive, direct effect of self-employment in farming is partly though not fully offset by negative, indirect effects working through income, social networks, and other variables. The negative effect of wage labor, relative to work on own farm, applies across a wide range of jobs. The effect is present for both younger and older workers. While the negative effect of wage labor appears to be partly transitory, it has not vanished after 2 years of wage employment. The positive effect of self-employment on happiness is consistent with results from Western countries, the main difference being that the effect in rural Vietnam is driven mainly by self-employment in farming, rather than other sectors.

Building on self-determination theory, other researchers have interpreted a positive effect of self-employment as the result of stronger feelings of autonomy among the selfemployed (Benz and Frey 2008a, b). We point out that employment category may also affect fulfilment of other psychological needs than autonomy, such as the needs for competence and relatedness. Our results are consistent with interpreting the positive effect of self-employment in agriculture as arising mainly from stronger feelings of relatedness among people working on their own farm.

Labor markets in developing countries are often viewed as 'segmented', in the sense that there are exogenous barriers to movement from one sector to another (Fields 2011). The presence of such barriers is often inferred from the observation of large income differences across sectors (Wachter 1974; Cain 1976). The results presented here suggest that this inference is not necessarily valid. Earnings differences may exist to compensate for differences in intrinsic (procedural) utility. If anything, our results suggest that earnings differences are too small to compensate wage workers for loss of procedural utility. The psychological burden of economic development is significant and policy makers and employers should consider how this burden may be addressed. We argued that the loss of subjective well-being incurred by wage workers may stem from weakened ties to family members. This implies that an important policy goal is to enable wage workers to maintain a fulfilling family life, e.g. by limiting work hours and protecting the right to vacations and decent living conditions.

One constraint of our study is that it covers rural areas only. No data are available on urban zones, yet many of the people who shift from farming to other types of employment move from rural to urban areas. Would the inclusion of urban people in the sample change our results? Results from China, which shares many similarities with Vietnam, suggest that it would not. Both Brockmann et al. (2008) and Knight and Gunatilaka (2010a) report that in spite of a large income advantage, urban Chinese report lower levels of happiness than their rural countrymen.

Apart from the findings on self-employment, other results are also of interest. First, we find remarkably low levels of subjective well-being in rural Vietnam. Some $48 \%$ of respondents report being 'not very' or 'not at all' pleased with their lives. Second, a strong, positive effect of own income on happiness is documented. There is also a significant, negative effect of other people's income. The overall, direct effect of income growth on happiness may therefore not be strong. On the other hand, there are statistically significant, positive effects of health and education on happiness. In this sense, economic growth is 
beneficial for subjective well-being, to the extent that growth facilitates improvements in health and education.

In general, the results presented here are remarkably in line with findings from other countries with completely different cultures and levels of development. For example, the effects of self-employment, relative income, marital status, health, schooling, age, and social capital are very similar to those reported for developed Western countries (Veenhoven 2012). ${ }^{15}$ This weakens the view that the happiness of rural dwellers in developing countries are determined by 'traditional', culture-specific values, which differ strongly from 'modern, western' values.

Acknowledgements We are grateful for the Journal editors' guidance and to seminar participants in Copenhagen and Hanoi and two anonymous referees for helpful comments.

Open Access This article is distributed under the terms of the Creative Commons Attribution 4.0 International License (http://creativecommons.org/licenses/by/4.0/), which permits unrestricted use, distribution, and reproduction in any medium, provided you give appropriate credit to the original author(s) and the source, provide a link to the Creative Commons license, and indicate if changes were made.

\section{References}

Alesina, A., Di Tella, R., \& MacCulloch, R. (2004). Inequality and happiness: Are Europeans and Americans different? Journal of Public Economics, 88(9-10), 2009-2042.

Andersson, P. (2008). Happiness and health: Well-being among the self-employed. Journal of SocioEconomics, 37(1), 213-236.

Benz, M., \& Frey, B. S. (2008a). Being independent is a great thing: Subjective evaluations of selfemployment and hierarchy. Economica, 75(298), 362-383.

Benz, M., \& Frey, B. S. (2008b). The value of doing what you like. Evidence from the self-employed in 23 countries. Journal of Economic Behavior \& Organization, 68(3-4), 445-455.

Berry, A. (2008). Labour markets in developing countries. In A. K. Dutt \& J. Ros (Eds.), International handbook of development economics, chapter 23 (Vol. 1, pp. 328-349). Cheltenham: Edward Elgar.

Berry, A. (2009). Improving measurement of Latin American inequality and poverty with an eye to equitable growth policy. IPD working paper series.

Berry, D. S., \& Hansen, J. S. (1996). Positive affect, negative affect, and social interaction. Journal of Personality and Social Psychology, 71(4), 796-809.

Bianchi, M. (2012). Financial development, entrepreneurship and job satisfaction. Review of Economic and Statistics, 94(1), 273-286.

Blanchflower, D. G. (2004). Self-employment: More may not be better. Swedish Economic Policy Review, 11(2), 15-73.

Blanchflower, D. G., \& Oswald, A. J. (1998). What makes an entrepreneur? Journal of Labor Economics, 16(1), 26-60.

Blanchflower, D. G., Oswald, A. J., \& Stutzer, A. (2001). Latent entrepreneurship across nations. European Economic Review, 45(4-6), 680-691.

Brockmann, H., Delhey, J., Welzel, C., \& Yuan, H. (2008). The China puzzle: Falling happiness in a rising economy. Journal of Happiness Studies, 10(4), 387-405.

Cain, G. (1976). The challenge of segmented labor market theories to orthodox theories. Journal of Economic Literature, 14(4), 1215-1257.

CIEM et al. (2013). Characteristics of the Vietnamese rural economy. Evidence from a 2012 rural household survey in 12 provinces of Vietnam. Hanoi: Central Institute of Economic Management, available at: http://www.ciem.org.vn/en/hoptacquocte/duanciem/tabid/303/articletype/ArticleView/ articleId/1046/default.aspx.

Cummins, R. A. (2000). Personal income and subjective well-being: A review. Journal of Happiness Studies, 1(2), 133-158.

${ }^{15}$ Gender is an exception. Studies in Western countries tend to find positive effects of being female, the opposite emerges here. 
Dalton, R. J., Pham, M. H., Pham, T. N., \& Ngu-Ngoc, T. O. (2002). Social relations and social capital in Vietnam: Findings from the 2002 world values survey. International Journal of Comparative Sociology, 1(3-4), 369-386.

De Jong, G. F., Chamratrithirong, A., \& Tran, Q. G. (2002). For better, for worse: Life satisfaction consequences of migration. International Migration Review, 36(3), 838-863.

Deaton, A. (2008). Income, health and wellbeing around the world: Evidence from the Gallup World Poll. The Journal of Economic Perspectives, 22(2), 53-72.

Deci, E. L., \& Ryan, R. M. (1985). Intrinsic motivation and self-determination in human behavior. New York: Plenum.

Deci, E. L., \& Ryan, R. M. (2000). The 'what' and 'why' of goal pursuits: Human needs and the selfdetermination of behavior. Psychological Inquiry, 11(4), 227-268.

Easterlin, R. (1974). Does economic growth improve the human lot? Some empirical evidence. In P. A. David \& M. W. Reder (Eds.), Nations and households in economic growth: Essays in honor of Moses Abramowitz. New York: Academic Press.

Falco, P., Maloney, W. F., Rijkers, B., \& Sarrias, M. (2012). Heterogeneity in subjective wellbeing. An application to occupational allocation in Africa. Policy research working paper 6244. Washington, DC: World Bank.

Fields, G. (2011). Labor market analysis for developing countries. Labour Economics, 18(S1), S16-S22.

Frey, B. S., Benz, M., \& Stutzer, A. (2004). Introducing procedural utility: Not only what, but also how matters. Journal of Institutional and Theoretical Economics, 160, 377-401.

Fuchs-Schündeln, N. (2009). On preferences for being self-employed. Journal of Economic Behavior \& Organization, 71(2), 162-171.

Graham, C. (2005a). Insights on development from the economics of happiness. The World Bank Research Observer, 20(2), 201-231.

Graham, C. (2005b). The economics of happiness: Insights on globalization from a novel approach. World Economics, 6(3), 41-55.

Graham, C., \& Petinatto, S. (2001). Happiness, markets and democracy: Latin America in comparative perspective. Journal of Happiness Studies, 2(3), 237-268.

Helliwell, J., Layard, R., \& Sachs, J. (2012). World happiness report. New York: Earth Institute.

Kahnemann, D., \& Deaton, A. (2010). High income improves evaluation of life but not emotional wellbeing. PNAS, 107(38), 16489-16493.

Kleibergen, F., \& Paap, R. (2006). Generalized reduced rank tests using the singular value decomposition. Journal of Econometrics, 133(1), 97-126.

Knight, J., \& Gunatilaka, R. (2010a). The rural-urban divide in China: Income but not happiness? The Journal of Development Studies, 46(3), 506-534.

Knight, J., \& Gunatilaka, R. (2010b). Great expectations? The subjective well-being of rural-urban migrants in China. World Development, 38(1), 113-124.

Lewis, A. C. (1954). Economic development with unlimited supplies of labor. The Manchester School, 22(2), 139-191.

Markussen, T., Fibæk, M., Tarp, F., \& Tuan, N. D. A. (2014). The happy farmer. Self-employment and subjective well-being in rural Vietnam. UNU-WIDER working paper 2014/108.

McMillan, M. S., \& Rodrik, D. (2011). Globalization, structural change and productivity growth. NBER working paper 17143 .

Monk-Turner, E., \& Turner, C. G. (2012). Subjective wellbeing in a southwestern province in China. Journal of Happiness Studies, 13(2), 357-369.

Powdthavee, N. (2008). Putting a price tag on friends, relatives and neighbours: Using surveys of life satisfaction to value social relationships. The Journal of Socioeconomics, 37(4), 1459-1480.

Ranis, G., \& Fei, J. C. H. (1961). A theory of economic development. American Economic Review, 51(4), 533-565.

Ravallion, M., \& van de Walle, D. (2008). Does rising landlessness signal success or failure for Vietnam's agrarian transition? Journal of Development Economics, 87(2), 191-209.

Senik, C. (2004). When information dominates comparison. Learning from Russian subjective panel data. Journal of Public Economics, 88(9-10), 2099-2133.

Stiglitz, J. E. (1974). Alternative theories of wage determination. Quarterly Journal of Economics, 88(2), 194-227.

Stock, J. H., \& Yogo, M. (2005). Testing for weak instruments in linear IV regressions. In D. W. K. Andrews \& J. H. Stock (Eds.), Identification and inference for econometric models: Essays in honor of Thomas Rothenberg. Cambridge: Cambridge University Press.

Teal, F. (1996). The size and sources of economic rents in a developing country manufacturing labour market. Economic Journal, 106(437), 963-976. 
Todaro, M. P. (1969). A model of labor migration and urban unemployment in less developed countries. American Economic Review, 59(1), 138-148.

Veenhoven, R. (1984). Conditions of happiness. Dordrecht: Reidel Publ. Co.

Veenhoven, R. (2012). Does happiness differ across cultures? In H. Selin \& G. Davey (Eds.), Happiness across cultures. Views of happiness and quality of life in non-western cultures. Dordrecht: Springer.

Wachter, M. (1974). Primary and secondary labor markets: A critique of the dual approach. Brookings Papers on Economic Activity, 5(3), 637-680.

World Values Survey. (2001, 2006). Data downloaded from www.worldvaluessurvey.org. 